\title{
CONTRIBUTION OF FISH CONSUMPTION TO CADMIUM AND LEAD INTAKES IN COASTAL COMMUNITIES OF WEST KALIMANTAN, INDONESIA
}

\author{
Zainal Arifin and Dede Falahudin \\ Research Center for Oceanography. Indonesian Institute of Sciences (LIPI). Jakarta, Indonesia \\ *Correspondence author: zain003@lipi.go.id
}

Received: December 2016 Accepted: January 2017

\begin{abstract}
Consumption of both marine and freshwater fishes is considered as a healthy way to obtain diet, but the ingestion of contaminated fishes remains a concern. Our study is conducted to asses cadmium $(\mathrm{Cd})$ and lead $(\mathrm{Pb})$ contents in various fishes consumed by coastal communities in six districts of West Kalimantan (Indonesia) and their health risks to the communities. Specifically, the objectives of this study are to determine the average weekly intakes (AWIs) of cadmium and lead based on dietary intake of fishes, then estimate health risk associated with fish consumption using the risk quotients (RQs) method. We also use food frequency questionnaires (FFQ) filled by 696 respondents to assess fish consumption habit of the communities in West Kalimantan who consumed up to 30 fish species in 2012 and 2013. Our results show that their average weekly fish consumption is $135.7 \pm 66.3$ g per week, which contributes to AWI values of $0.38 \pm 0.55 \mu \mathrm{g} / \mathrm{kg}$ body weight (bw) per week for $\mathrm{Cd}$ and $0.87 \pm$ $0.65 \mu \mathrm{g} / \mathrm{kg}$ bw per week for $\mathrm{Pb}$. The RQ values indicate a low risk of $\mathrm{Pb}$ coming from fish consumption, but the $\mathrm{RQ}$ value for $\mathrm{Cd}$ is high for the children age group. In conclusion, fish consumption in the six districts of coastal communities in West Kalimantan generally does not pose any health risk from $\mathrm{Pb}$. Conversely, $\mathrm{Cd}$ intake from fish consumption has a potential risk for children. As such, regular monitoring and additional studies are needed on potential contribution of $\mathrm{Cd}$ intake from other food sources.
\end{abstract}

Keywords: average weekly intake (AWI), risk quotients (RQs), heavy metals, health risk, Kalimantan

\section{INTRODUCTION}

Heavy metals, especially cadmium (Cd) and lead $(\mathrm{Pb})$, have pervasive distribution and rising concentrations in aquatic ecosystems, thus posing threats to the environment and human health (Domiano et al., 2011; Adel et al., 2016). These heavy metals, released into aquatic systems by anthropogenic activities, are accumulating in water, suspended solids and sediments, and subsequently in aquatic biota. Therefore, communities with a dietary habit based on fish consumption may have a higher risk to be exposed to and ingest heavy metals.
Ongoing anthropogenic activities in the West Kalimantan Province of Indonesia may contribute to heavy metals intake in humans. Three main sources of anthropogenic activities in the province are large usage of pesticides in palm oil industries, a large number of boats as river transportation and illegal mining activities (Arifin et al., 2014). These activities increasingly release and remobilize heavy metals into aquatic systems that finally enter the food chain. Previous studies have shown that almost all commercial fishes and shellfishes contain heavy metals, with some of them accumulate high $\mathrm{Pb}$ and $\mathrm{Cd}$ in their tissues (Setyawati and Nofritra, 2002; Purbonegoro 
et al., 2014). Indeed, more than $90 \%$ of heavy metals uptake to humans is mainly through water and food intake (Hassan et al., 2016).

On the other hand, traditional fisheries contribute up to $67 \%$ of the total fishery production in West Kalimantan (BPS, 2013), where the coastal communities rely on marine and freshwater fishes as a main source of protein. High in micronutrients but low in saturated fatty acids, fishes are known to be beneficial to health (Hoekstra et al., 2013; Afonso et al., 2013; Neff et al., 2014). However, contaminated fishes bring health risks to humans (Harris et al., 2009; Gao et al., 2016). Previous studies have reported that exposure to $\mathrm{Cd}$ and $\mathrm{Pb}$ through fish consumption causes major diseases in humans such as renal failure, liver damage and symptoms of chronic toxicity in the kidney (Bosch et al., 2016).

With the need for estimating the health risks of contaminants through dietary intake, previous literatures have employed a number of methods including the hazard quotient (HQ), target hazard quotient (THQ) and hazard index (Zhu et al., 2015; Saleh and Marie, 2015; Zhu et al., 2016). Additionally, the food frequency questionnaire (FFQ) approach can be performed to study fish consumption habit in coastal communities. The FFQ is simple and low cost, yet it can obtain complete information from large populations, therefore the method is commonly used in dietary intake assessments (Athanasiadou et al., 2016; Saeedi et al., 2016; Moghames et al., 2016; Nybacka et al., 2016).

Therefore, our study assesses the risk of heavy metals intake to humans via fish consumption in West Kalimantan. The objectives of our study are two-folds; firstly to assess the average weekly intakes (AWIs) of $\mathrm{Cd}$ and $\mathrm{Pb}$ based on dietary intake of fish; secondly to estimate risk levels of $\mathrm{Cd}$ and $\mathrm{Pb}$ contaminants to the coastal communities in West Kalimantan. The risk quotient (RQ) method is adopted in this study for estimating the risk of contaminants via fish consumption as has been applied in other studies (MPP-EAS, 1999; USEPA, 2000; Chien et al., 2006; Sioen et al., 2009).

\section{MATERIALS AND METHODS}

\section{Determination of Metal Concentration in Fish Samples}

The field sampling component was conducted between 2012 and 2013. Fish species were selected based on the dietary habits of coastal communities, with a total of 30 species of fish/shellfish consisted of 8 species of freshwater fish and 24 species of marine fish. $\mathrm{Cd}$ and $\mathrm{Pb}$ contents in fish tissues were determined following a method by the ASEAN-Canada Cooperative Programme on Marine Science II (McPherson et al.,1999). Each sample of fish or shellfish was analyzed in triplicate in the following manner. Tissue sample of each specimen was heated in an oven at $105^{\circ} \mathrm{C}$ for approximately 12 hours, then the dried tissue sample was ground using an agate mortar. A portion of the powdered sample (about $1 \mathrm{~g}$ weighed with a precision of $0.1 \mathrm{mg}$ ) was poured into a glass beaker, added with a strong acid $\left(\mathrm{HNO}_{3}\right)$ and heated on a hot plate at $85^{\circ} \mathrm{C}$ for approximately 8 hours. Then $\mathrm{H}_{2} \mathrm{O}_{2}$ was added to the sample to achieve a complete digestion process.

The liquid sample was then analyzed using a Flame Atomic Absorption Spectrophotometry (Varian SpectrAA-20 Plus). The detection limits of the instrument for $\mathrm{Cd}$ and $\mathrm{Pb}$ are $2 \mu \mathrm{g} / \mathrm{L}$ and 10 $\mu \mathrm{g} / \mathrm{L}$, respectively. The reference material (SRM NIST 1566B), which has a certified Cd content of $2.48 \pm 0.08 \mathrm{mg} / \mathrm{kg}$ and $\mathrm{Pb}$ content of 0.3808 $\pm 0.09 \mathrm{mg} / \mathrm{kg}$, was used to validate the methods; where we obtained $2.51 \pm 0.06 \mathrm{mg} / \mathrm{kg}$ for $\mathrm{Cd}$ and $0.337 \pm 0.17 \mathrm{mg} / \mathrm{kg}$ for $\mathrm{Pb}(\mathrm{N}=3)$ in our study.

\section{Dietary Survey}

The fish consumption habit of the communities was investigated using food frequency questionnaires (FFQ). There were 696 respondents from six districts of the West Kalimantan Province, i.e., Sambas, Kota Singkawang, Bengkayang, Kota Pontianak, Kubu Raya and Sanggau (Figure 1). The fish consumption habit information include fish species, the frequency and the quantity of fishes consumed. Respondents were also interviewed for their profile which consists of information on their age, sex, body weight and occupational groups. 


\section{Cadmium and Lead Intake}

The estimated average weekly intakes (AWIs) of $\mathrm{Cd}$ and $\mathrm{Pb}$ from fish consumption are calculated based on a formula from MPP-EAS (1999) and USEPA (2000):

$$
\text { AWI }=\frac{A \times B}{B W}
$$

where AWI is the average weekly intake of each contaminant $(\mu \mathrm{g} / \mathrm{kg}$ body weight per week), A is weekly fish consumption ( $\mathrm{g}$ per week), B is concentration of contaminant $(\mu \mathrm{g} / \mathrm{g}$ ww) and BW is body weight $(\mathrm{kg})$.
The health risk of respondents due to fish consumption was calculated using the risk quotient (RQ) method (MPP-EAS, 1999):

$$
\mathbf{R Q}=\frac{\mathbf{A W I}}{\mathbf{T W I}}
$$

where AWI is the average weekly intake $(\mu \mathrm{g} / \mathrm{kg}$ bw per week) and TWI is the tolerable weekly intake. The TWI for $\mathrm{Cd}$ is $2.5 \mu \mathrm{g} / \mathrm{kg}$ bw per week based on the Panel on Contaminants in the Food Chain of the European Food Safety Authority (Alexander et al., 2009). For $\mathrm{Pb}$, we adopt a provisional tolerable weekly intake (PTWI) of $25 \mu \mathrm{g} / \mathrm{kg}$ bw per week based on the FAO/WHO Joint Expert Committee on Food Additives and Contaminants, JECFA) (Arnich et al., 2012).

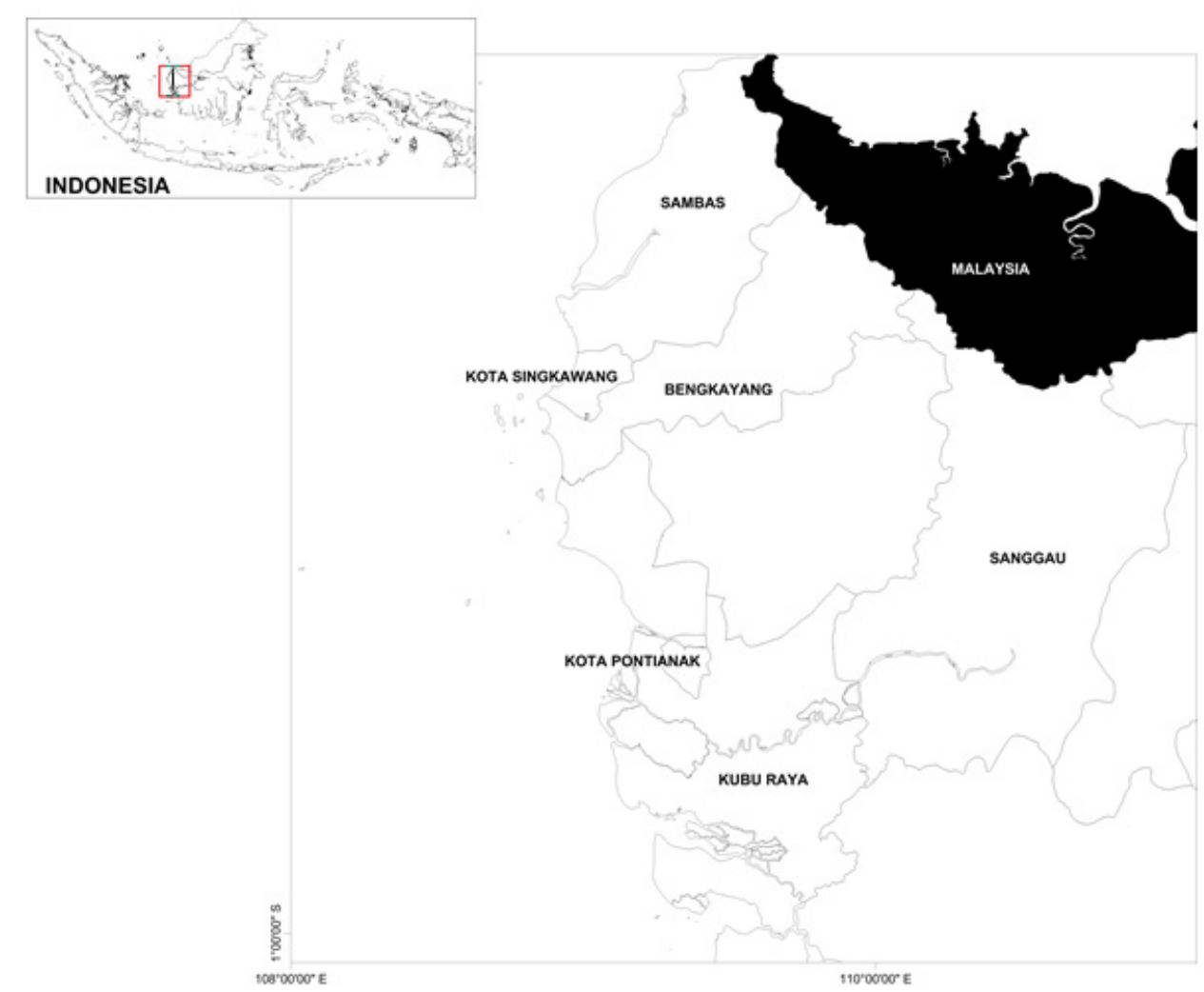

Figure 1. Study sites consisting six districts in the West Kalimantan Province.

\section{Statistical Analysis}

All statistical analyses are estimated using SPSS23 (IBM Corp.) and figures are presented using the ggplot2 function in the $\mathrm{R}$ environment ( $\mathrm{R}$ v3.3.1; R Core team). The normality and homogeneity of data are determined using the Shapiro-Wilkinson and the Levene's tests. If the data are not normally distributed, a nonparametric procedure (Kruskal-Wallis $\mathrm{H}$ test) is applied to the data.

\section{RESULTS}

\section{Profile of Respondents}

A total of 696 respondents were interviewed from six districts of the West Kalimantan Province, with their ages ranging from 12 to 65 years old. The respondents are composed of almost equal numbers of male and female (Table $1)$. The average values of their body weight are $51.4 \mathrm{~kg}$ (range of $22.3-62.0 \mathrm{~kg}$ ) for the male 
group and $45.4 \mathrm{~kg}$ (range of $20.7-59.2 \mathrm{~kg}$ ) for the female group.

Table 1. Profile of respondents of the FFQ survey in West Kalimantan, Indonesia.

\begin{tabular}{lll}
\hline & $\begin{array}{l}\text { Respondents } \\
(\mathrm{N})\end{array}$ & $\begin{array}{l}\text { Frequency } \\
(\%)\end{array}$ \\
\hline Gender: & & \\
Male & 332 & 47.7 \\
Female & 364 & 52.3 \\
& & \\
Age (year): & & \\
Children (<14) & 38 & 5.5 \\
Adolescent (15-24) & 200 & 28.7 \\
Adult (25-44) & 299 & 43.0 \\
Senior (45-65) & 159 & 22.8 \\
& & \\
Occupation: & & \\
Student & 191 & 27.4 \\
Civil servant & 137 & 19.7 \\
Private sector & 188 & 27.0 \\
Fisherman & 58 & 8.3 \\
Housewife & 122 & 17.5 \\
& & \\
Residence: & & \\
Kubu Raya & 153 & 22.0 \\
Sanggau & 44 & 6.3 \\
Sambas & 133 & 19.1 \\
Kota Pontianak & 131 & 18.8 \\
Kota Singkawang & 119 & 17.1 \\
Bengkayang & 116 & 16.7 \\
\hline
\end{tabular}

\section{Average Weekly Intake of Fish}

The fish consumption of six coastal communities in West Kalimantan is highly variable, ranging from daily to once a week. In general, the frequency of fish consumption of the coastal communities in West Kalimantan is 2.1 \pm 0.8 times per week, with an average weekly intake of fish of $134.6 \pm 59.5 \mathrm{~g}$ per week. The fish consumption habit of the coastal communities is significantly different between gender groups (Kruskal-Wallis $\mathrm{H}$ test, $\chi^{2}(1)=4.68$, p-value $=$ $0.03)$, but similar between age groups (KruskalWallis $\mathrm{H}$ test, $\chi^{2}(3)=4.63, \mathrm{p}=0.20$ ).

Fish species consumed by the respondents from six districts are: island mackerel, hairtail fish, barred queenfish, Indo-Pacific king mackerel,
Indian mackerel, goldband goatfish and all marine catfishes (Table 2).

\section{Estimation of the Average Weekly Intake of Cd and $\mathbf{P b}$}

The estimated weekly intake (AWI) of $\mathrm{Cd}$ and $\mathrm{Pb}$ through fish consumption for different age and gender groups is presented in Figure 2. Fish consumption contributes to an average $\mathrm{Cd}$ intake of $1.01 \pm 1.68,0.35 \pm 0.28,0.35 \pm 0.35$, and $0.31 \pm 0.30 \mu \mathrm{g} / \mathrm{kg}$ bw per week for the children, adolescent, adult and senior age groups, respectively. In contrast, $\mathrm{Pb}$ intake is more than twice higher than the $\mathrm{Cd}$ intake, on average 1.78 $\pm 1.40,0.88 \pm 0.65,0.80 \pm 0.45$ and $0.73 \pm 0.36$ $\mu \mathrm{g} / \mathrm{kg}$ bw per week for the children, adolescent, adult and senior age groups, respectively. The weekly intakes of $\mathrm{Cd}$ and $\mathrm{Pb}$ are significantly different between age groups with children having the highest intake (Kruskal-Wallis H test, $\chi_{\mathrm{Cd}}^{2}(3)$ $\left.=25.06, \chi_{\mathrm{Pb}}^{2}(3)=40.20, \mathrm{p}<0.05\right)$. And, male and female gender groups have similar intake rates (Kruskal-Wallis H test, $\chi_{\mathrm{Cd}}^{2}(1)=0.04, \chi_{\mathrm{Pb}}^{2}(1)=$ 3.3, $\mathrm{p}>0.05$ ) (Figure 2).

\section{Estimation of Risk Quotient of Cd and Pb}

Risk assessment due to the dietary intakes of $\mathrm{Cd}$ and $\mathrm{Pb}$ shows that RQ values, calculated based on the gender and age groups are mostly far below the maximum risk quotient value (i.e. RQ $=1.0$ ) for all respondents from all the six districts (Table 3 ). The RQ values of $\mathrm{Cd}$ and $\mathrm{Pb}$ range from one-hundredth to half of the maximum RQ. Both $\mathrm{RQ}_{\mathrm{Cd}}$ and $\mathrm{RQ}_{\mathrm{Pb}}$ for male and female respondents are significantly different (Kruskal-Wallis $\mathrm{H}$ test, $\left.\chi_{\mathrm{Cd}}^{2}(1)=0.04, \chi_{\mathrm{Pb}}^{2}(1)=0.75, \mathrm{p}>0.05\right)$ and highly vary among respondents. Based on the age of respondents, $\mathrm{RQ}_{\mathrm{Cd}}$ values range from 0.12 to 0.41 (with an average of 0.15 ), and $\mathrm{RQ}_{\mathrm{pb}}$ values range from 0.03 to 0.07 (average of 0.20 ). There is also a significant difference between age groups (Kruskal-Wallis H test, $\chi_{\mathrm{Cd}}^{2}(3)=25.06, \chi_{\mathrm{Pb}}^{2}(3)=$ 91.64, $\mathrm{p}<0.05$ ). 
Table 2. Cadmium and lead concentrations (mean \pm standard deviation), $\mathrm{N}=$ number of fish samples.

\begin{tabular}{|c|c|c|c|c|c|}
\hline No & English Name (Local Name) & Scientific Name & $\mathrm{N}$ & $\begin{array}{c}\mathrm{Cd} \\
(\mu \mathrm{g} / \mathrm{g} \mathrm{ww})\end{array}$ & $\begin{array}{c}\mathrm{Pb} \\
(\mu \mathrm{g} / \mathrm{g} \mathrm{ww})\end{array}$ \\
\hline & Freshwater fFsh & & & & \\
\hline 1 & Striped snake head (gabus) & Channa striata & 6 & $0.05 \pm 0.04$ & $0.32 \pm 0.10$ \\
\hline 2 & Striped snake head (toman) & Channa sp1. & 2 & $0.03 \pm 0.01$ & $0.09 \pm 0.12$ \\
\hline 3 & Wallago (juara) & Wallago attu & 7 & $0.06 \pm 0.04$ & $0.30 \pm 0.13$ \\
\hline 4 & Sheatfish (lais sengarat) & Belodontichthys dinema & 6 & $0.03 \pm 0.00$ & $0.18 \pm 0.00$ \\
\hline 5 & Three spot gourami (biawan/sepat) & Trichogaster trichopterus & 3 & $0.02 \pm 0.00$ & $0.26 \pm 0.00$ \\
\hline 6 & Common sheatfish (lais lajong) & Cryptogoterus apogon & 7 & $0.03 \pm 0.00$ & $0.29 \pm 0.11$ \\
\hline 7 & Asian redtail catfish (baung) & Macrones nemurus & 10 & $0.04 \pm 0.04$ & $0.29 \pm 0.08$ \\
\hline \multirow[t]{2}{*}{8} & Pangas catfish (patin laut) & Pangasius pangasius & 1 & $0.01 \pm 0.00$ & $0.18 \pm 0.00$ \\
\hline & Marine Fish & & & & \\
\hline 9 & Hairtail fish (timah-timah) & Trichiurus sp, & 12 & $0.05 \pm 0.04$ & $0.33 \pm 0.26$ \\
\hline 10 & Marine catfish (duri kera) & Arius sp1. & 11 & $0.04 \pm 0.02$ & $0.32 \pm 0.04$ \\
\hline 11 & Marine catfish (duri udang) & Arius sp2. & 14 & $0.04 \pm 0.04$ & $0.46 \pm 0.69$ \\
\hline 12 & Marine catfish (belukang) & Arius sp3. & 11 & $0.03 \pm 0.03$ & $0.30 \pm 0.10$ \\
\hline 13 & Marine catfish (duri putih) & Arius sp4. & 20 & $0.04 \pm 0.03$ & $0.53 \pm 0.68$ \\
\hline 14 & Marine catfish (duri moncong) & Arius sp5. & 11 & $0.04 \pm 0.04$ & $0.32 \pm 0.30$ \\
\hline 15 & Marine catfish (sembilang) & Arius sp6. & 9 & $0.05 \pm 0.08$ & $0.32 \pm 0.18$ \\
\hline 16 & Spotted catfish (mayung jahan) & Arius maculatus & 1 & $0.04 \pm 0.00$ & $0.01 \pm 0.00$ \\
\hline 17 & Croaker fish (gulama tora) & Johnius sp1 & 10 & $0.07 \pm 0.03$ & $0.26 \pm 0.24$ \\
\hline 18 & Croaker fish gulama papan) & Johnius sp2. & 12 & $0.04 \pm 0.03$ & $0.33 \pm 0.34$ \\
\hline 19 & Goldband gotfish (biji nangka) & Upeneus moluccensis & 9 & $0.05 \pm 0.00$ & $1.39 \pm 0.00$ \\
\hline 20 & Doublelined Tonguesole (sebelah merah) & Paraplagusia bilineata & 5 & $0.03 \pm 0.02$ & $0.51 \pm 0.35$ \\
\hline 21 & Barred queenfish (talang-talang) & Chorinemus tala & 3 & $0.10 \pm 0.00$ & $0.31 \pm 0.00$ \\
\hline 22 & Indian mackerel (kembung laki-laki) & Rastrelliger kanagurta & 4 & $0.10 \pm 0.00$ & $0.54 \pm 0.00$ \\
\hline 23 & Indo Pasific king mackerel (tenggiri papan) & Scomberomorus guttatus & 2 & $0.05 \pm 0.00$ & $1.14 \pm 0.00$ \\
\hline 24 & Island mackerel (kembung) & Rastrelliger faughni & 3 & $0.35 \pm 0.00$ & $0.28 \pm 0.00$ \\
\hline 25 & Kelee shad (tamban) & Hilsa kelee & 8 & $0.10 \pm 0.04$ & $0.40 \pm 0.38$ \\
\hline 26 & Black pomfret (bawal peda-peda) & Parastromateus niger & 5 & $0.06 \pm 0.00$ & $0.15 \pm 0.00$ \\
\hline 27 & Cuttlefish (sotong kodok) & Sepia sp. & 4 & $0.13 \pm 0.00$ & $0.27 \pm 0.00$ \\
\hline 28 & Mangrove cockle (kerang kepah) & Anandontea alba & 38 & $0.07 \pm 0.03$ & $0.29 \pm 0.13$ \\
\hline 29 & Squid (cumi) & Teuthida sp. & 2 & $0.11 \pm 0.00$ & $0.25 \pm 0.00$ \\
\hline \multirow[t]{3}{*}{30} & Blood cockle (kerang darah) & Anadara sp. & 52 & $0.10 \pm 0.11$ & $0.16 \pm 0.24$ \\
\hline & National Standard (Indonesia) & & & 0.10 & 0.30 \\
\hline & European Union Standard & & & 0.05 & 0.30 \\
\hline
\end{tabular}

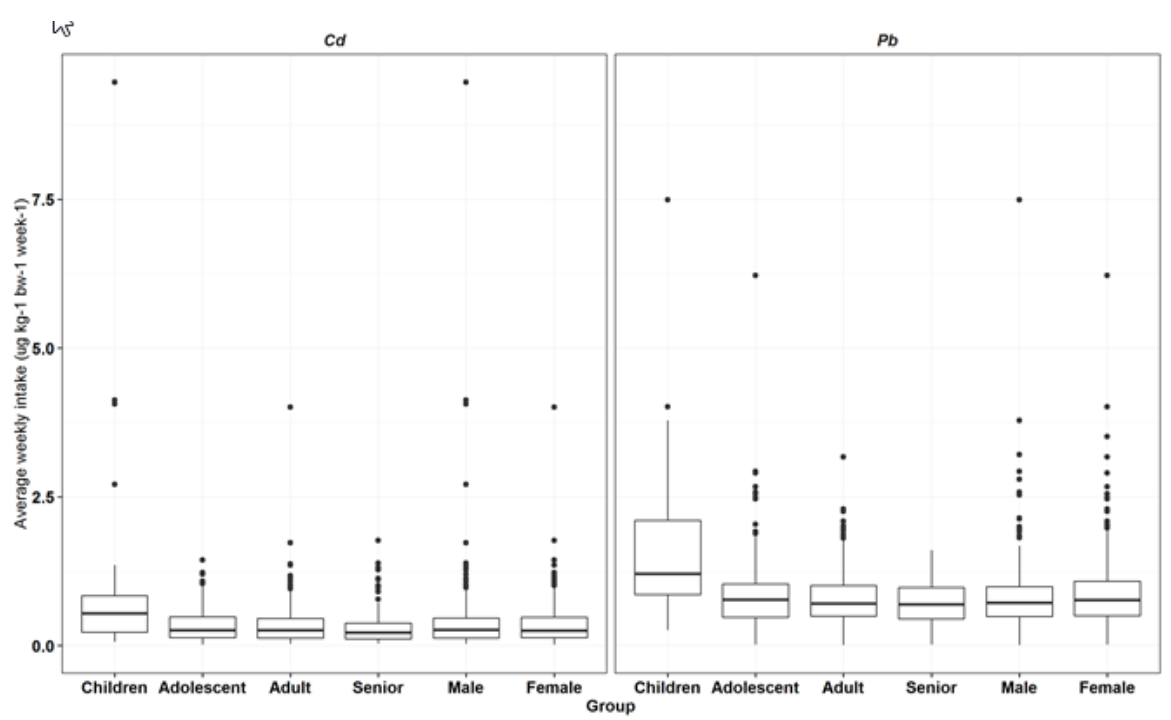

Figure 2. Distribution of average weekly intake of $\mathrm{Cd}$ and $\mathrm{Pb}(\mu \mathrm{g} / \mathrm{kg}$ bw per week) among different age and gender groups. The graph is shown as median $(5,25,75$, and 95 percentile) and outliers. 
Table 3. $\mathrm{RQ}$ values of $\mathrm{Pb}$ and $\mathrm{Cd}$ intake.

\begin{tabular}{llll}
\hline Classification & \multicolumn{2}{l}{ RQ value } \\
& & $\mathrm{Cd}$ & $\mathrm{Pb}$ \\
\hline \multirow{2}{*}{ Sex } & Male & $0.16 \pm 0.26$ & $0.03 \pm 0.02$ \\
& Female & $0.14 \pm 0.14$ & $0.04 \pm 0.03$ \\
& Children $(<14)$ & $0.41 \pm 0.66$ & $0.07 \pm 0.06$ \\
\multirow{2}{*}{ Age } & Adolescent $(15-24)$ & $0.14 \pm 0.11$ & $0.04 \pm 0.03$ \\
& Adult (25-44) & $0.14 \pm 0.14$ & $0.03 \pm 0.02$ \\
& Senior $(>45)$ & $0.12 \pm 0.12$ & $0.03 \pm 0.01$ \\
\hline
\end{tabular}

Note: maximum RQ value $=1.0$

\section{DISCUSSION}

Fish is a major part of human diet in many provinces in Indonesia, however, the problems of coastal pollution due to industrial and development activities resurface almost every year. Therefore, it is not surprising that numerous studies have been carried out on measuring non-essential and toxic metals such as $\mathrm{Hg}, \mathrm{Cd}$, and $\mathrm{Pb}$ in many parts in Indonesia (Kamaruzzaman et al., 2010; Putri et al., 2012; Koesmawati and Arifin, 2015). Fish consumption is one of the routes for heavy metal uptake from food sources (Waheed et al., 2013). And, there is a positive correlation between the amount of fish consumed and heavy metal intake by humans (Sioen et al., 2009). Therefore, it is important for the community to have reliable information related to risks and benefits of fish consumption (e.g. Sidhu, 2003; Neff et al., 2014).

Our study shows that out of 30 species of fish consumed in West Kalimantan, 13\% of fish species exceed the safety level for Cd concentration $(0.10 \mu \mathrm{g} / \mathrm{g} \mathrm{ww})$ set by the Indonesian National Standard in SNI 73872009 (SNI, 2009). However, if the number is compared to the regulation established by the EU, there are $57 \%$ of fish species exceeding the permitted value (0.05 $\mu \mathrm{g} / \mathrm{g} \mathrm{ww})$ (European Commission, 2006). In contrast to $\mathrm{Cd}, 67 \%$ of $\mathrm{Pb}$ concentrations in fish species are beyond the maximum value $(0.30$ $\mu \mathrm{g} / \mathrm{g} \mathrm{ww}$ ) set by the SNI and EC standard (SNI, 2009; European Commission, 2006). Therefore, it is clearly urgent to inform the consumers, not only the benefits of consuming fishes, but also the risk of consuming fishes contaminated with heavy metals $\mathrm{Cd}$ and $\mathrm{Pb}$.
In our current study, the age group, body weight group and consumption habit are major factors in differentiating the average weekly intakes (AWIs). The weekly intakes of $\mathrm{Cd}$ and $\mathrm{Pb}$ highly vary between age groups, likely reflecting different preferences and quantities in fish consumption as well as body weights. In general, the average weekly intakes of cadmium and lead for all age groups are below the established TWI of Cd $(2.5 \mu \mathrm{g} / \mathrm{kg}$ bw per week) and PTWI of $\mathrm{Pb}(25 \mu \mathrm{g} / \mathrm{kg}$ bw per week); though for several respondents, their $\mathrm{Cd}$ intakes exceed the safety level. The weekly intakes of $\mathrm{Cd}$ and $\mathrm{Pb}$ in the children group, for example, tend to be higher compared to the rest of age groups (Figure 2). Although children have a similar amount of fish consumption with other age groups in our study, because of their smaller body weights, they have higher doses of toxicant per kilogram of body mass. In all, our study suggests that with the current habit of fish consumption and the concentration of $\mathrm{Cd}$ and $\mathrm{Pb}$ in fishes, the consumption of fishes from traditional markets in West Kalimantan does not lead to high intake of $\mathrm{Cd}$ and $\mathrm{Pb}$ for the local coastal communities.

It should be noted that the intake of heavy metals depends on several associated factors, such as ethnicity, consumption habit, gender, age and body weight (Wilhelm et al., 2002; Vieira et al., 2011). In our study, the children age group shows the highest intake of $\mathrm{Cd}$ and $\mathrm{Pb}$ compared to other age groups. High intakes of both metals in the children age group also could be contributed to the feeding behaviour and food preference of their parents, especially for fisherman communities whose majority are low income families. Indeed, a previous study (Afonso et al., 2013) showed that consumption habits have a significant role in heavy metal intake. This condition raises a concern on potential cadmium over-exposure in children.

The estimated $\mathrm{Cd}$ and $\mathrm{Pb}$ AWIs herein are only based on fish consumption, thus do not consider other sources of cadmium and lead intake such as vegetables, meat and rice $(e, g$. Zhou et al., 2016). Consequently, the total dietary intake of cadmium might be higher than the current estimation for the coastal communities of West Kalimantan, especially for the children age group. Therefore, future works need to consider possible $\mathrm{Cd}$ intake from other food sources. 
Risk assessment due to dietary intakes of cadmium and lead shows that the RQ values are generally far below the maximum risk quotient value $(\mathrm{RQ}=1.0)$ for all respondents, except for several respondents belonging to the children age group. $\mathrm{Pb}$ concentrations in fish from coastal waters of West Kalimantan do not pose any health problem. In contrast, $\mathrm{Cd}$ intake from fishes may risk a portion of the children age group whose $R Q$ values could reach the safely level $\left(R Q_{C d}\right.$ $=1.0$ ). Therefore, preventive steps should be taken particularly for children as different age groups have different potential health risks. In addition, children with their lightweight body masses, limited knowledge on food preference, developing nervous systems, higher intestinal absorption and lower renal excretion; are the most vulnerable group to heavy metal exposure (Ilmiawati et al., 2015; Bosch et al., 2016). Therefore with long term exposure, children are more susceptible to the risk of heavy metals toxicity especially cadmium compared to adults. Furthermore, any risk assessment of heavy metals also should takes into account some potential $\mathrm{Cd}$ and $\mathrm{Pb}$ intakes coming from other food sources and a combination effect from other paths of heavy metals intake.

\section{CONCLUSION}

The average weekly fish consumption for six districts in West Kalimantan in 2012 and 2013 is $135.7 \pm 66.3 \mathrm{~g}$ per week, which contributes to the intakes of $\mathrm{Cd}$ and $\mathrm{Pb}$ up to $0.38 \pm 0.55 \mu \mathrm{g} /$ $\mathrm{kg}$ bw per week for $\mathrm{Cd}$ and $0.87 \pm 0.65 \mu \mathrm{g} / \mathrm{kg}$ bw per week for $\mathrm{Pb}$, respectively. The Risk quotient (RQ) values of $\mathrm{Pb}$ are less than 1 . Hence, there is no significant health risk of $\mathrm{Pb}$ to the coastal communities in West Kalimantan, if dietary intakes only come from fish consumption. In contrast, the risk of $\mathrm{Cd}$ intake is potentially high for children age group.

\section{ACKNOWLEDGEMENT}

This research was funded by the Research Competitive Program of the Indonesian Institute of Sciences (2010-2013) to ZA. We would like to thank the entire research team, i.e., Triyoni Purbonegoro, Abdul Rozak and Eston Matondang for assisting us in the field and laboratory. We would like to thank Dr. Andreas Kunzmann and an unanimous reviewer for improving the manuscript.

\section{REFERENCES}

Adel, M., Dadar, M., Fakhri, Y., Oliveri-Conti, G. and Ferrante, M. (2016). Heavy metal concentration in muscle of pike ( Esox lucius Linnaeus, 1758) from Anzali international wetland, southwest of the Caspian Sea and their consumption risk assessment. Toxin Reviews, 35(3-4), 217-223. http://doi.org/10 .1080/15569543.2016.1223694

Afonso, C., Cardoso, C., Lourenço, H. M., Anacleto, P., Bandarra, N. M., Carvalho, M. L., and Nunes, M. L. (2013). Evaluation of hazards and benefits associated with the consumption of six fish species from the Portuguese coast. J. Food Comp. Analy., 32(1), 59-67. http://doi.org/10.1016/j. jfca.2013.06.008

Alexander, J., Benford, D., Cockburn, A., Cravedi, J.P., Dogliotti, E., Di Domenico, A. and Verger, P. (2009). SCIENTIFIC OPINION Cadmium in food Scientific Opinion of the Panel on Contaminants in the Food Chain. EFSA J., 980, 1-139.

Arifin, Z., Ismail, M. F. A., Purbonegoro, T., Falahudin, D., and Putri, M. R. (2014). Heavy metals contaminants in coastal waters of West Kalimantan. Research Centre for Oceanography, Indonesian Institute of Science.

Arnich, N., Sirot, V., Rivière, G., Jean, J., Noël, L., Guérin, T. and Leblanc, J.C. (2012). Dietary exposure to trace elements and health risk assessment in the 2nd French Total Diet Study. Food Chem. Toxicol., 50(7), 2432 2449. http://doi.org/10.1016/j.fct.2012.04.016

Athanasiadou, E., Kyrkou, C., Fotiou, M., Tsakoumaki, F., Dimitropoulou, A., Polychroniadou, E. and Michaelidou, A.M. (2016). Development and Validation of a Mediterranean Oriented CultureSpecific Semi-Quantitative Food Frequency Questionnaire. Nutrients, 8(9), 522. http://doi. org/10.3390/nu8090522 
Bosch, A. C., O’Neill, B., Sigge, G. O., Kerwath, S. E. and Hoffman, L. C. (2016). Heavy metals in marine fish meat and consumer health: a review. J. Sci. Food Agr., 96(1), 32-48. http:// doi.org/10.1002/jsfa.7360

BPS. (2013). Kalimantan Barat In Figure 2013. BPS-Statistics of Kalimantan Barat.

Chien, L.-C., Yeh, C.Y., Jiang, C.-B., Hsu, C.S. and Han, B.C.(2006). Estimation of acceptable mercury intake from fish in Taiwan. http://doi. org/10.1016/j.chemosphere. 2006.10.036.

Damiano, S., Papetti, P. and Menesatti, P. (2011). Accumulation of heavy metals to assess the health status of swordfish in a comparative analysis of Mediterranean and Atlantic areas. Mar. Pol. Bul., 62(8), 1920-1925. http://doi. org/10.1016/j.marpolbul.2011.04.028.

European Commission. (2006). Setting maximum levels for certain contaminants in foodstuffs, Commission Regulation (EC) No 1881/2006. Official Journal of the European Union, 77, $1-13$.

Gao, M., Klerks, P. L., Wu, X., Chen, H. and Xie, L. (2016). Metal Concentrations in Sediment And Biota of the Huludao Coast in Liaodong Bay and Associated Human and Ecological Health Risks. Arch. Environ. Contam. Toxicol., 71(1), 87-96. http://doi.org/10.1007/ s00244-016-0274-8.

Harris, S. A., Urton, A., Turf, E. and Monti, M. M. (2009). Fish and shellfish consumption estimates and perceptions of risk in a cohort of occupational and recreational fishers of the Chesapeake Bay. Environ. Res., 109(1), 108-115. http://doi.org/10.1016/j. envres.2008.08.012.

Hassan, A. R. H. A., Zeinhom, M. M. A., AbdelWahab, M. A., and Tolba, M. H. (2016). Heavy Metal Dietary Intake and Potential Health Risks for University Hostel Students. Biol. Trace Elem. Res., http://doi.org/10.1007/ s12011-015-0451-z.

Hoekstra, J., Hart, A., Owen, H., Zeilmaker, M., Bokkers, B., Thorgilsson, B., and Gunnlaugsdottir, H. (2013). Fish, contaminants and human health: Quantifying and weighing benefits and risks. Food Chem.
Toxicol., 54, 18-29. http://doi.org/10.1016/j. fct.2012.01.013.

Ilmiawati, C., Yoshida, T., Itoh, T., Nakagi, Y., Saijo, Y., Sugioka, Y. and Kayama, F. (2015). Biomonitoring of mercury, cadmium, and lead exposure in Japanese children: a crosssectional study. Envir. Health Preventive Med., 20(1), 18-27. http://doi.org/10.1007/ s12199-014-0416-4.

Kamaruzzaman, B. Y., Ong, M. C. and Rina, S. Z. (2010). Concentration of $\mathrm{Zn}, \mathrm{Cu}$ and $\mathrm{Pb}$ in some selected marine fishes of the Pahang coastal waters, Malaysia. American J. App. Sci., 7(3), 309-314.

Kjellström, T., and Nordberg, G. F. (1978). Model of Cadmium in the Human Being. Envir. Res., 16(1), 248-269. http://doi.org/10.1016/00139351(78)90160-3.

Koesmawati, T. A. and Arifin, Z. (2015). Mercury and Arsenic Content in Seafood Samples From the Jakarta Fishing Port, Indonesia. Marine Research in Indonesia, 40(1), 9. http://doi. org/10.14203/mri.v40i1.76.

McPherson, C. A., Chapman, P. M., Vigers, G. A. and Ong, K. S. (1999). ASEAN Marine Water Quality Criteria: Contextual Framework, Principles, Methodology and Criteria for 18 Parameters. ASEAN Marine Environmental Quality Criteria - Working Group (AMEQCWG), ASEAN-Canada Cooperative Programme on Marine Science - Phase II $(C P$. EVS Environment Consultants, North Vancouver and Department of Fisheries, Malaysia.

Moghames, P., Hammami, N., Hwalla, N., Yazbeck, N., Shoaib, H., Nasreddine, L., and Naja, F. (2016). Validity and reliability of a food frequency questionnaire to estimate dietary intake among Lebanese children. Nutr. J., 15, 4. http://doi.org/10.1186/s12937-0150121-1.

MPP-EAS. (1999). Malacca Straits: Refined Risk Assessment. MPP-EAS Technical Report No.23/PEMSEA Technical Report No. 1, 89p. GEF/UNDP/IMO Regional Programme for the Prevention and Management of Marine Pollution in the eas asian Seas (MPP-EAS)/ Partnerships in Environmental Management 
for the Seas of East Asia (PEMSEA), Quezon City, Philippines.

Neff, M. R., Bhavsar, S. P., Ni, F. J., Carpenter, D. O., Drouillard, K., Fisk, A. T. and Arts, M. T. (2014). Risk-benefit of consuming Lake Erie fish. Envir. Res., 134, 57-65. http://doi. org/10.1016/j.envres.2014.05.025.

Nybacka, S., Bertéus Forslund, H., Wirfält, E., Larsson, I., Ericson, U., Warensjö Lemming, E. and Lindroos, A. K. (2016). Comparison of a web-based food record tool and a food-frequency questionnaire and objective validation using the doubly labelled water technique in a Swedish middle-aged population. J. Nutr. Sci., 5, e39. http://doi. org/10.1017/jns.2016.29.

Purbonegoro, T., Damar, A. and Arifin, Z. (2014). Heavy metals in suspended solids and sediments of Kapuas eastuary, West Kalimantan. Jurnal Oseanologi Dan Limnologi Di Indonesia, 40(1), 55-70.

Putri, L. S. E., Prasetyo, A. D. and Arifin, Z. (2012). Green Mussel (Perna Viridis L.) As Bioindicator Of Heavy Metals Pollution At Kamal Estuary, Jakarta Bay, Indonesia.. $J$. Envir. Res. Dev., 6(3), 389-396.

Saeedi, P., Skeaff, S. A., Wong, J. E. and Skidmore, P. M. L. (2016). Reproducibility and Relative Validity of a Short Food Frequency Questionnaire in 9-10 Year-Old Children. Nutr., 8(5). http://doi.org/10.3390/ nu8050271.

Saleh, Y. S. and Marie, M.A. S. (2015). Assessment of metal contamination in water, sediment, and tissues of Arius thalassinus fish from the Red Sea coast of Yemen and the potential human risk assessment. Envir. Sci. Pol. Res., 22(7), 5481-5490. http://doi. org/10.1007/s11356-014-3780-0.

Setyawati, T. and Nofritra. (2002). Mercury quantity in the some oysters sold in Pontianak city of the West Kalimantan Province. Research report of Faculty of Mathemathics and Natural Sciences, Tanjung Pura University.
Sidhu, K. S. (2003). Health benefits and potential risks related to consumption of fish or fish oil. Regul. Toxicol. Pharmacol., 38(3), 336-344. http://doi.org/10.1016/j.yrtph.2003.07.002.

Sioen, I., De Henauw, S., Van Camp, J., Volatier, J.L. and Leblanc, J.C. (2009). Comparison of the nutritional-toxicological conflict related to seafood consumption in different regions worldwide. Regul. Toxicol. Pharmacol., 55(2), 219-228. http://doi.org/10.1016/j. yrtph.2009.07.003.

SNI. (2009). The maximum level of heavy metals contamination in food. National Standardization Agency of Indonesia.

USEPA. (2000). Guidance for Assessing Chemical Contaminant Data for Use in Fish Advisories Volume 2 Risk Assessment and Fish Consumption Limits Third Edition. Office of Science and Technology Office of Water U.S. Environmental Protection Agency Washington, DC.

Vieira, C., Morais, S., Ramos, S., DelerueMatos, C. and Oliveira, M. B. P. P. (2011). Mercury, cadmium, lead and arsenic levels in three pelagic fish species from the Atlantic Ocean: Intra- and inter-specific variability and human health risks for consumption. Food Chem. Toxicol., 49(4), 923-932. http://doi. org/10.1016/j.fct.2010.12.016.

Waheed, S., Malik, R. N. and Jahan, S. (2013). Health risk from As contaminated fish consumption by population living around River Chenab, Pakistan. Envir. Toxicol. Pharmacol., 36(2), 579-587. http://doi. org/10.1016/j.etap.2013.05.015.

Zhou, H., Yang, W.T., Zhou, X., Liu, L., Gu, J.-F., Wang, W.L. and Liao, B.-H. (2016). Accumulation of Heavy Metals in Vegetable Species Planted in Contaminated Soils and the Health Risk Assessment. Int. J. Envir. Res. Public Health., 13(3), 289. http://doi. org/10.3390/ijerph13030289. 
Zhu, F., Qu, L., Fan, W., Wang, A., Hao, H., Li, X., and Yao, S. (2015). Study on heavy metal levels and its health risk assessment in some edible fishes from Nansi Lake, China. Envir. Monit. Assess.,, 187(4), 161. http://doi. org/10.1007/s10661-015-4355-3.
Zhu, H., Xu, Y., Yan, B., Guan, J., Zhou, Q. and Liang, Y. (2016). Risk assessment of heavy metals contamination in sediment and aquatic animals in downstream waters affected by historical gold extraction in Northeast China. Hum. Ecol. Risk Assess: Int. J., 22(3), 693705. http://doi.org/10.1080/10807039.2015.1 104626. 